\title{
Studi Unjuk Kerja Smart Microgrid Sistem Hibrid di Jurusan Teknik Elektro Universitas Udayana Kampus Bukit Jimbaran
}

\author{
I.P. Arsikaputra ${ }^{1}$, I.A.D. Giriantari ${ }^{2}$, W.G. Ariastina ${ }^{3}$ \\ Submission: 09-03-2020, Accepted: 21-06-2020
}

\begin{abstract}
Most of the power plants use fossil energy sources, while fossil energy has several undesirable effects. To overcome this, it is necessary to develop in electricity that is by using renewable energy as a source of electrical energy. Some examples of electrical renewable energy sources used are solar energy and wind energy. Renewable energy as electricity generation can be developed using a microgrid concept, generation with more than one power plant. The combination of different types of power plants is often called a hybrid power plant. One example is a hybrid power plant with a smart microgrid network system at the Department of Electrical Engineering, Faculty of Engineering, Udayana University, which has been operating since 2017, which is a collaboration between Udayana University and the Ministry of Energy and Mineral Resources (ESDM). This smart microgrid requires a study of the energy supply system of the power generation in order to know its performance to serve the DH building load. The study will analyze the data in October 2018. Research results show that smart microgrids cannot fully meet the electricity load in October 2018. The electrical energy load of $4330 \mathrm{kWh} \mathrm{DH}$ building is supplied by PLTS 333,383 kWh, PLTB 121.07 kWh, and supply of 803.57 batteries. kWh The shortage of electrical energy from the microgrid system is supplied by PLN by $1591.7 \mathrm{kWh}$ and when overproduction, PLN can get energy from the $541 \mathrm{kWh}$ microgrid. Battery charging energy is $1894.38 \mathrm{kWh}$. The use of renewable energy in the DH building reached $63.24 \%$.
\end{abstract}

Keywords - Microgrid, PLTS, PLTB, Battery

Intisari- Pembangkit listrik yang digunakan untuk memenuhi kebutuhan listrik saat ini sebagian besar menggunakan sumber energi fosil, sedangkan energi fosil memiliki beberapa dampak yang tidak diinginkan. Untuk mengatasi hal tersebut, maka diperlukan adanya pengembangan dalam kelistrikan yakni dengan menggunakan energi terbarukan sebagai sumber energi listrik. Beberapa contoh sumber energi listrik yang digunakan yaitu energi matahari dan energi angin. Penggunaan energi terbarukan sebagai pembangkit listrik dapat dikembangkan dengan menggunakan sebuah konsep microgrid, yakni pembangkitan dengan lebih dari satu pembangkit. Perpaduan pembangkit listrik dengan jenis berbeda sering disebut dengan pembangkit listrik hibrid. Salah satu contohnya yaitu pembangkit listrik hibrid dengan sistem jaringan smart microgrid pada Jurusan Teknik Elektro Fakultas Teknik Universitas Udayana sudah beroperasi sejak 2017 yang merupakan kerjasama antara Universitas Udayana dan

\footnotetext{
${ }^{1}$ Mahasiswa, Pascasarjana Magister Teknik Elektro Universitas Udayana, Jln. Kebo Iwa Utara Gang Merak Denpasar, Kode Pos:80117; (HP: 082236087705; email:arsikaputra@gmail.com)

${ }^{2,3}$ Dosen Jurusan Teknik Elektro dan Komputer Fakultas Teknik Universitas Udayana, Jln. Jalan Kampus Bukit Jimbaran 80361 INDONESIA (telp: 0361-703315; fax: 0361-4321; e-mail: dayu.giriantari@unud..ac.id, w.ariastina@unud.ac.id )
}

Kementrian Energi Sumber Daya Mineral (ESDM).

Smart microgrid ini membutuhkan studi dari sistem suplai energi dari pembangkitan tenaga listrik tersebut agar mengetahui unjuk kerjanya untuk melayani beban gedung DH. Studi menganalisis data bulan Oktober 2018. Hasil Penelitian menunjukan smart microgrid tidak dapat sepenuhnya memenuhi beban listrik pada bulan Oktober 2018. Beban energi listrik $4330 \mathrm{kWh}$ gedung DH disuplai oleh PLTS 333,383 kWh, PLTB 121,07 kWh, dan suplai dari baterai 803,57 $\mathrm{kWh}$. Kekurangan energi listrik dari sistem microgrid dicatu oleh PLN sebesar 1591,7 kWh dan saat produksi berlebihan, PLN dapat energi masuk dari microgrid $541 \mathrm{kWh}$. Energi pengisian baterai sebesar 1894,38 kWh. Pemakaian energi baru terbarukan pada gedung DH mencapai $63,24 \%$.

Kata Kunci-Microgrid, PLTS, PLTB, Baterai.

\section{PENDAHULUAN}

Pembangkit listrik saat ini masih menggunakan sumber energi fosil dengan presentase paling besar dalam pembangkitan energi listrik. Persediaan cadangan energi dari fosil makin berkurang dimana pada tahun 2016 pemakaian energi dari fosil total 74,14\% [1]. Ketergantungan produsen listrik pada energi fosil masih tinggi sementara sumber energi baru terbarukan di Indonesia tinggi pula [2]. Diperlukan pengembangan dari energi baru terbarukan sebagai pembangkit energi listrik untuk mengurangi penggunaan energi dari fosil.Pemerintah Indonesia mengatur pengembangan energi baru terbarukan yang dalam Rencana Umum Energi Nasional menargetkan 23\% dari total rencana pembangkit memanfaatkan energi baru terbarukan pada tahun 2025 [3]. Pengembangan energi baru terbarukan saat ini seperti Pembangkit Listrik Tenaga Surya (PLTS) dan Pembangkit Listrik Tenaga Bayu (PLTB) yang memanfaatkan energi matahari dan energi angin sebagai sumber energi utamanya. PLTS dan PLTB dipakai pada pembangkit listrik hibrid pada jaringan microgrid.

Salah satu penerapan konsep pembangkit listrik hibrid dengan sistem jaringan microgrid pada area pendidikan terletak pada Jurusan Teknik Elektro Fakultas Teknik Universitas Udayana. Jaringan microgrid sistem hibrid Jurusan Teknik Elektro terdiri dari Pembangkit Listrik Tenaga Surya (PLTS 26,4 kW, Pembangkit Listrik Tenaga Bayu (PLTB) $5 \mathrm{~kW}$, sistem baterai $240 \mathrm{kVAh}$ dan Generator Set 20 kVA [4][5][14]. Jaringan microgrid sistem hibrid ini terhubung dengan jaringan utama PLN dibangun atas kerjasama Jurusan Teknik Elektro Unud dengan Kementrian Energi dan Sumber Daya Mineral (Kemen ESDM) terletak pada Gedung DH. Jurusan Teknik Elektro Unud memiliki tiga gedung yaitu gedung DI untuk fasilitas laboratorium, gedung DJ untuk fasilitas administrasi dan gedung DH untuk aktifitas 
belajar mengajar [4][5]. Jaringan microgrid sistem hibrid di Jurusan Teknik Elektro diharapkan membantu menjaga kontinuitas suplai energi listrik ke beban gedung DH maka diperlukan studi untuk mengetahui unjuk kerja jaringan microgrid sistem hibrid di Jurusan Teknik Elektro untuk mengetahui energi listrik yang dihasilkan pada Pembangkit Listrik Tenaga Surya (PLTS), Pembangkit Listrik Tenaga Bayu (PLTB) dan sistem baterai untuk memenuhi kebutuhan energi listrik pada gedung $\mathrm{DH}$.

Berdasarkan latar belakang tersebut, maka pada penelitian ini dilakukan studi mengenai berapa daya listrik yang dibangkitkan pembangkit pada jaringan microgrid dan energi listrik yang dihasilkan sehingga dapat diketahui unjuk kerja PLTS, PLTB dan sistem baterai dalam sistem smart microgrid yang terhubung dengan jaringan utama PLN pada gedung DH serta diketahui persentase pemanfaatannya oleh smart microgrid.

\section{MICROGRID}

Microgrid merupakan sistem distribusi skala kecil dengan berbagai macam sumber energi, baik dari sumber energi fosil maupun energi baru terbarukan yang memiliki sistem interkoneksi beban yang terdiri dari sumber energi terdistribusi yang meliputi mikro turbin, fuel cells, $P V$ dan lain sebagainya dengan media penyimpanan energi: flywheels, kapasitor dan baterai serta beban yang fleksibel [6][9][14].

Pembangkit listrik dalam microgrid karena bersumber dari energi fosil maupun energi baru terbarukan dalam menghubungkannya menjadi satu sistem distribusi membutuhkan sistem manajemen yang cerdas yang disebut Smart Microgrid [4]. Sistem smart microgrid memungkinkan untuk mengontrol dua arah dari semua komponen berbeda dalam sistem distribusi dan biasanya terletak pada tegangan rendah serta dapat bekerja pada kondisi normal (grid connected) maupun kondisi darurat (islanded), sehingga meningkatkan kehandalan [4][6][8][9][14].

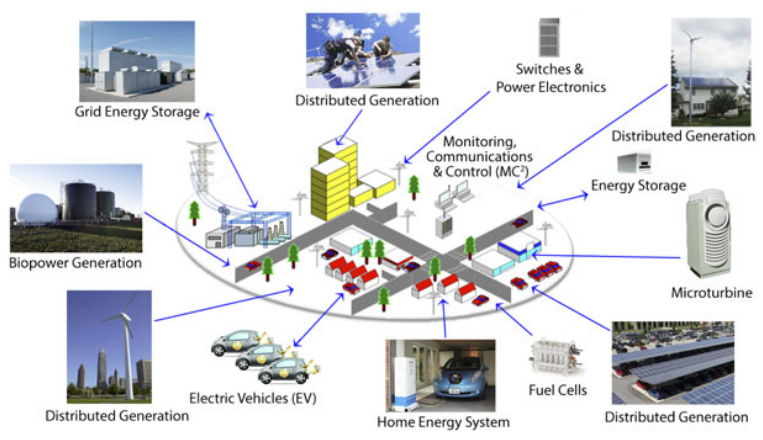

Gambar 1. Sistem Microgrid [7]

Pada Jurusan Teknik Elektro Fakultas Teknik Unud di atap Gedung DH terdapat Pembangkit Listrik Tenaga Surya (PLTS), Pembangkit Listrik Tenaga Bayu (PLTB), membentuk jaringan smart microgrid dengan baterai sebagai sistem penyimpanan energi listrik dan Generator Set yang berfungsi sebagai cadangan. Kombinasi berbagai sistem pembangkit bersumber dari energi baru terbarukan atau campuran disebut dengan sistem hibrid. Pemanfaatan energi baru terbarukan dalam microgrid sistem hibrid akan menghasilkan emisi gas rumah kaca yang rendah atau nol dan polusi yang lebih sedikit pada lingkungan [9]. Aplikasi pemanfaatan energi baru terbarukan saat ini sudah cukup banyak pada atap bangunan terutama PLTS seperti pada: sekolah, kantor, gedung pemerintah dan juga universitas [10], [11], [12], [13].

Smart Microgrid sistem hibrid di Jurusan Teknik Elektro (JTE) disuplai oleh sumber pembangkitan berupa PLTS, PLTB sistem penyimpanan energi menggunakan baterai leadacid dan Generator set yang terinterkoneksi dengan jaringan utama PLN pada tegangan rendah 220/380 V. Skema dari microgrid sistem hibrid di Jurusan Teknik Elektro (JTE) ditunjukan pada Gambar 2.

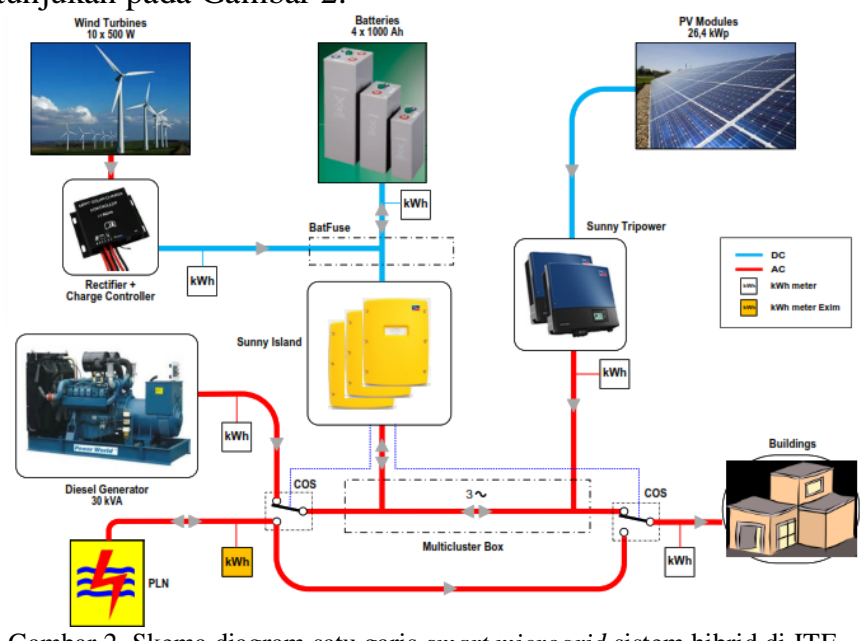

Gambar 2. Skema diagram satu garis smart microgrid sistem hibrid di JTE [13]

PLTS pada smart microgrid di JTE merupakan pembangkit listrik utama yang terdiri dari 2 array dari modul photovoltaic yang menggunakan modul Kyocera KU330-8BCA dengan daya maksimum pada iradiasi puncak sebesar $330 \mathrm{~W}$. Tegangan DC yang dihasilkan PLTS diubah menjadi tegangan AC 3 fasa oleh inverter Sunny Tripower 15000 TL yang dikontrol oleh bidectional inverter Sunny Island SMA S18OH-11.

PLTB merupakan salah satu sumber pembangkitan pada smart microgrid sistem hibrid di JTE dengan total total kapasitas $5 \mathrm{~kW}$ terdiri dari 10 turbin dengan kapasitas daya masing-masing $500 \mathrm{~W}$. Tegangan keluaran PLTB berupa tegangan AC 3 fasa dengan menggunakan penyearah diubah menjadi tegangan DC sebesar 48 VDC yang dimasukan pada pengatur pengisian baterai. PLTB diprioritaskan hanya untuk mengisi baterai saja.

Baterai merupakan sistem penyimpanan energi pada smart microgrid dengan jenis baterai Hoppecke Lead Acid berkapasitas total $192 \mathrm{kVAh}$. Baterai sepenuhnya dikontrol oleh biderctional inverter Sunny Island SMA S18-OH-11 saat pengisian dan pelepasan ke sistem smart microgrid. Bidirectional inverter mengatur pengisian baterai dari PLTS atau PLN dengan SOC (state of charge) minimum 20\% sampai SOC maksimum $98 \%$.

Bidirectional Inverter Sunny Island SMA S18-OH-11 dalam smart microgrid sistem hibrid di JTE mengatur smart microgrid bekerja dalam dua mode operasi yaitu on grid dan islanding. Pada kondisi on grid sistem microgrid dengan grid PLN dalam keadaan sinkron, bidirectional inverter akan 
DOI: https://doi.org/10.24843/MITE.2020.v19i01.P13

mereferensikan tegangan dan frekuensi dari PLN serta sebagai charge controller baterai. PLTS, PLN dan Baterai akan mensuplai beban gedung DH. Saat kondisi islanding bidirectional inverter akan melepaskan grid PLN dan melakukan seluruh pengaturan sistem smart microgrid meliputi pemberian referensi tegangan dan frekuensi serta melakukan manajemen daya pada PLTS, baterai dan generator set agar kontinuitas suplai energi listrik ke beban terjaga.

\section{METODE PENELITIAN}

Penelitian mengenai unjuk kerja smart microgrid ini dilakukan secara metode kualitatif dan kuantitatif..Sumber data yang digunakan dalam penelitian ini berupa data primer yang diperoleh dari data pengukuran (weather station, data logger dari pembangkit listrik sistem hibrid) dan studi literatur dari literatur yang berkaitan dengan tema pembahasan, seperti jurnal penelitian. Penelitian ini dilakukan di Jurusan Teknik Elektro Fakultas Teknik Universitas Udayana Kampus Bukit Jimbaran pada bulan Juni Sampai Oktober 2018 dan data dipergunakan data 1 bulan saja yaitu bulan Oktober 2018. Proses penelitian dimulai dengan mengidentifikasi sistem pembangkit listrik hibrid, pengumpulan teknis komponen terpasang pada microgrid sistem hibrid, mencari data cuaca potensi energi angin dan energi matahari, pengukuran data energi dari masing-masing pembangkit listrik hibrid dan analisis.

\section{IV.HASIL DAN PEMBAHASAN}

\section{A. Profil Beban Gedung DH JTE}

Gedung DH di Jurusan Teknik Elektro terdiri dari 7 ruangan kelas yang setiap ruangan terdapat beban listrik yang dgunakan sebagai sarana penunjang kegiatan belajar mengajar berupa: lampu penerangan, pengkondisi udara (AC), $L C D$ projector dan kotak kontak.

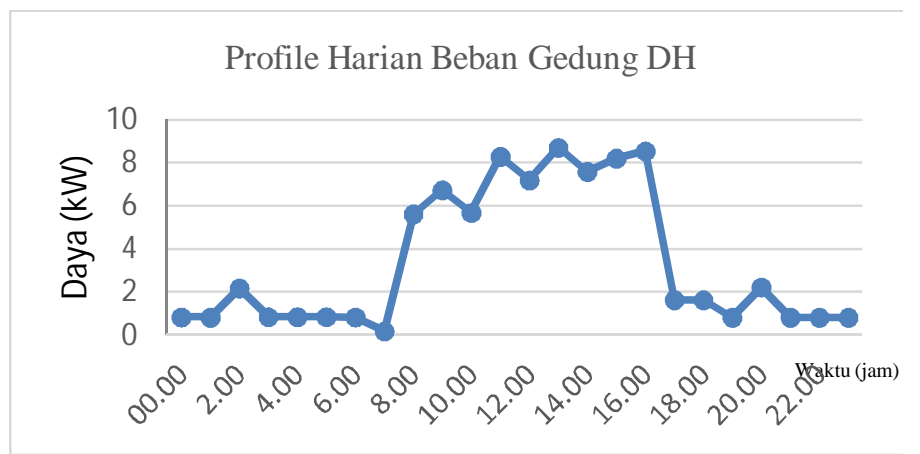

Gambar 3. Profil beban harian gedung DH JTE

Gambar 3 adalah data profil beban harian gedung DH selama 24 jam pada 14 Oktober 2018. Dari profil beban, terlihat aktifitas kegiatan perkuliahan di Jurusan Teknik Elektro dimulai pukul 8.00 WITA sampai pukul 17.00 WITA. Saat aktifitas perkuliahan beban yang terpakai di gedung DH adalah berupa lampu penerangan, pengkondisi udara (AC), LCD projector dan kotak kontak yang dipakai untuk mengisi baterai laptop. Beban puncak konsumsi daya listrik Gedung DH sebesar 8,70352 kW terjadi pada pukul 13.00 WITA. Pada Pukul 18.00 sampai 06.00 WITA beban gedung DH mengalami penurunan, karena tidak ada aktifitas perkuliahan. Beban terpakai saat itu adalah lampu penerangan di selasar Gedung DH, Gedung DI dan Gedung DJ.

\section{B. Analisis Keluaran Daya PLTS}

PLTS merupakan sumber pembangkit listrik utama yang langsung mensuplai beban gedung DH. Daya yang dibangkitkan oleh PLTS ditentukan oleh iradiasi matahari.Pengukuran iradiasi matahari yang diperoleh pada gedung DH dapat dilihat pada gambar 4, sedangkan daya yang dibangkitkan oleh PLTS ditunjukkan pada gambar 5.
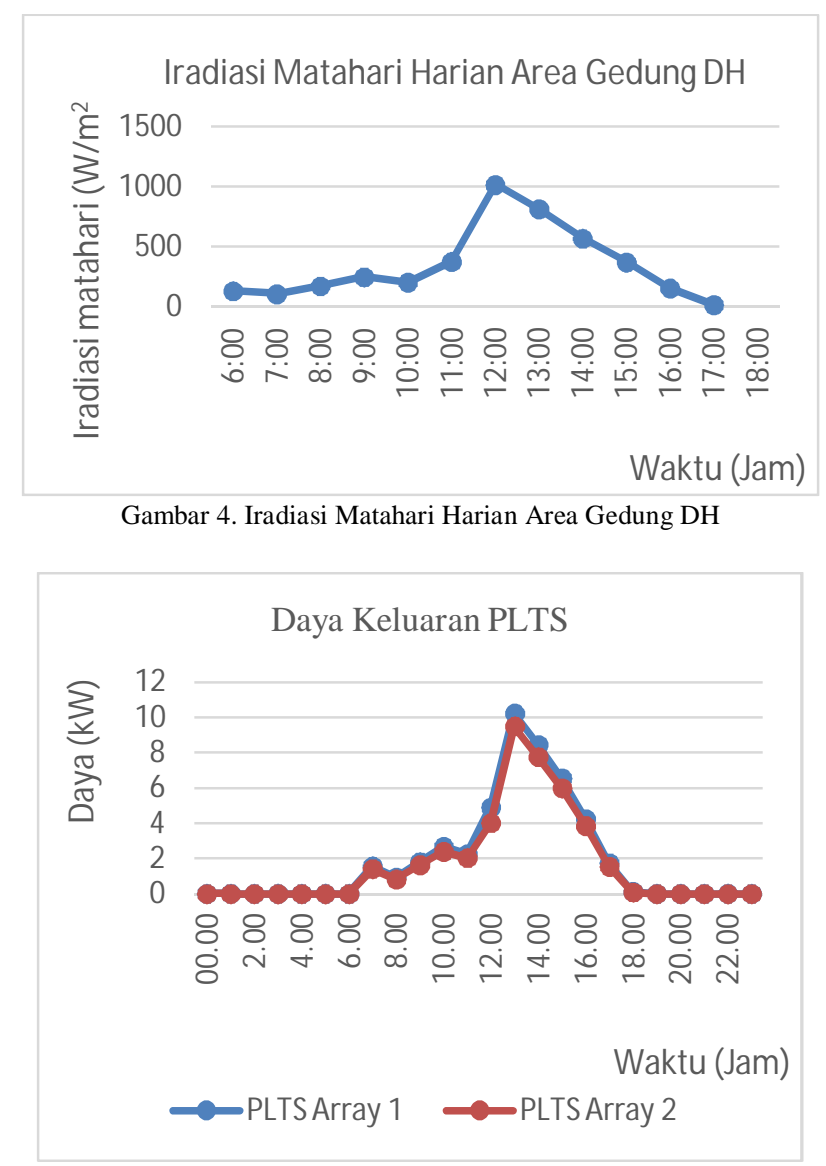

Gambar 5. Grafik Daya Keluaran PLTS Array 1 dan Array 2

Iradiasi matahari mempengaruhi daya keluaran dari PLTS. Gambar 4 memperlihatkan iradiasi harian pada area gedung DH pada tanggal 14 Oktober 2018 yang berkolerasi dengan daya keluaran pada PLTS Array 1 dan Array 2. Berdasarkan gambar 4 dan 5, iradiasi tertinggi dan daya tertinggi diperoleh pada pukul 12.00 WITA, dan akan menurun hingga pukul 17.00 WITA karena pada pukul tersebut matahari mulai terbenam. Daya keluaran dari PLTS pada siang hari pukul 12.00 WITA sebesar 10,22972 kW untuk PLTS array 1 dan 9,50399 kW untuk PLTS array 2.

p-ISSN:1693 - 2951; e-ISSN: 2503-2372 
C. Analisis Keluaran Daya PLTB

PLTB dipengaruhi kecepatan angin untuk menghasilkan daya listrik.
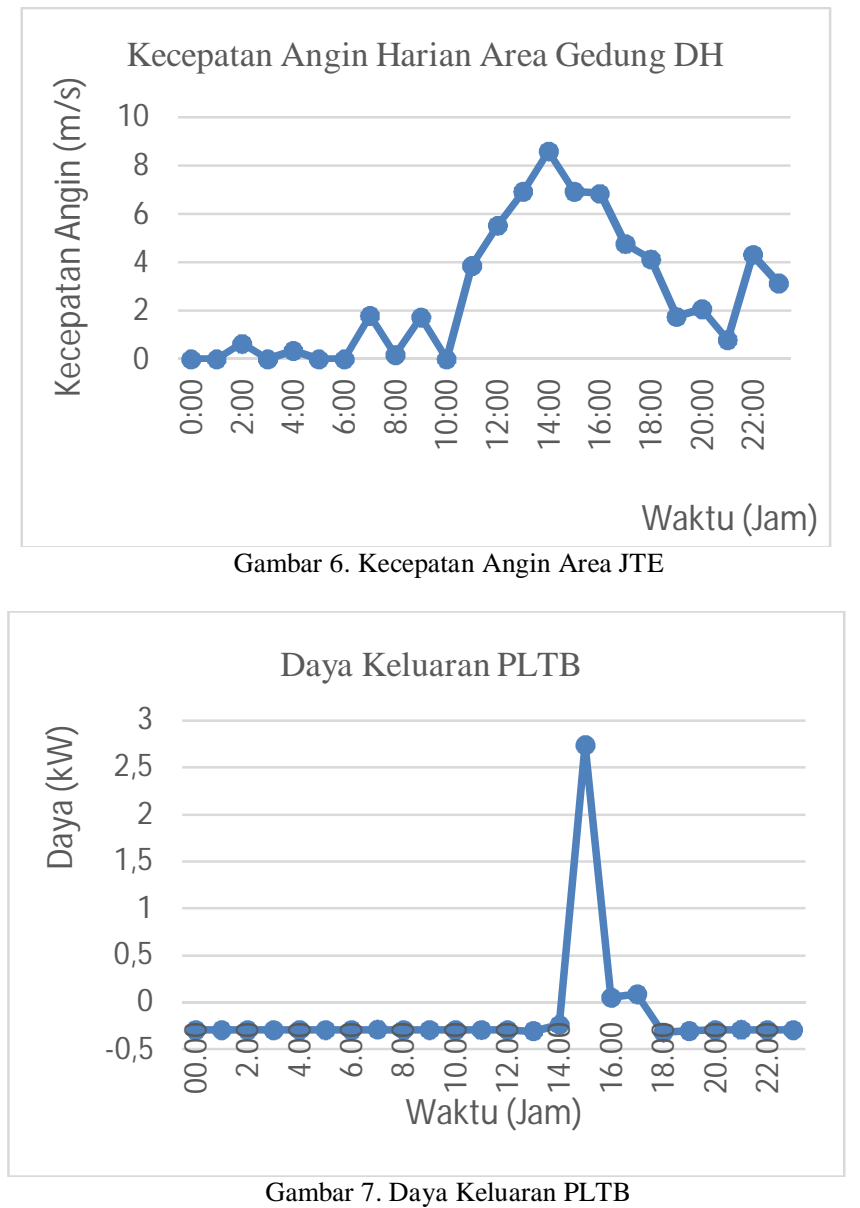

Kecepatan Angin yang berubah-ubah di area gedung DH terlihat pada gambar 6 yang mempengaruhi kecepatan putar turbin angin sehingga daya keluaran dari PLTB berubah pula seperti pada gambar 7 . Kecepatan angin rata-rata pada 14 Oktober 2018 di area gedung DH 2,683708 m/s. PLTB membangkitkan daya maksimum $2,73637 \mathrm{~kW}$ pada pukul 15.00 WITA sepenuhnya dipakai untuk mengisi baterai.

Daya keluaran PLTB bernilai negatif mengindikasikan PLTB tidak menghasilkan daya tetapi ada aliran daya dari sistem smart microgrid menuju ke charge controller MPPT Epsolar IT3415ND dan dummy load.

\section{Analisis Daya Baterai}

Daya saat charge dan discharge baterai sepenuhnya dikontrol bidirectional inverter sunny island. Baterai akan discharge (lingkaran merah) saat daya pembangkitan PLTS lebih kecil dari kebutuhan daya beban Gedung DH dan saat daya dibangkitkan PLTS lebih besar dari kebutuhan daya beban gedung DH baterai pada kondisi charging (lingkaran hijau).

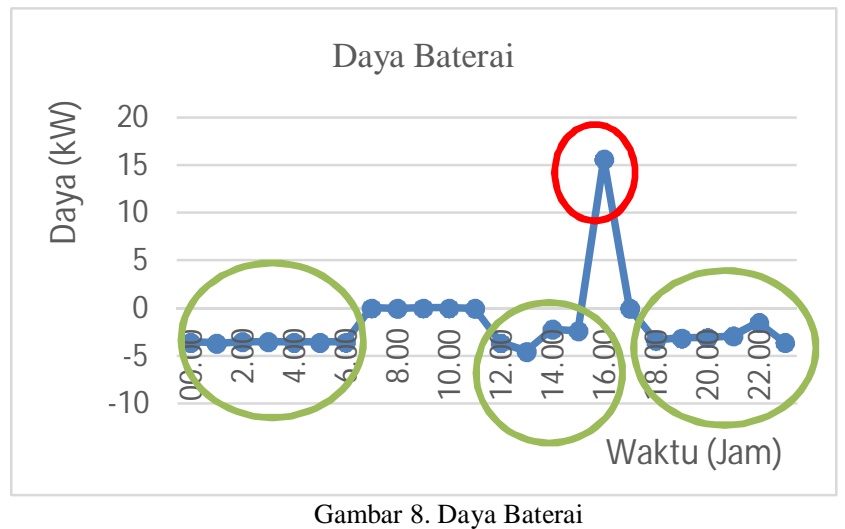

Berdasarkan gambar 8 dapat dianalisis bahwa jika daya baterai bernilai positif maka baterai berada dalam kondisi discharging (lingkaran merah), dimana baterai melepaskan daya untuk mensuplai daya beban pada gedung DH. Baterai dalam smart microgrid terlihat pada posisi discharging pada pukul 8.00 sampai dengan 10.00 WITA, 14.00 WITA dan 16.00 WITA dengan daya maksimum $15,62909 \mathrm{~kW}$ pada pukul 16.00 WITA. Pada Gambar 8 terlihat pula baterai dalam kondisi charging pada pukul 18.00 sampai dengan 06.00 WITA, pukul 12.00 sampai dengan 15.00 WITA dengan daya maksimum 3,67221 kW pada pukul 01.00 WITA

\section{E. Analisis Daya Grid PLN}

PLN pada sistem smart microgrid sistem hibrid JTE merupakan pemasok daya listrik kedua setelah PLTS dan Baterai. Dalam kondisi on grid PLN dalam keadaan standby jika kebutuhan daya beban gedung DH lebih rendah dari daya yang dibangkitkan PLTS dan Baterai, sebaliknya PLN akan membantu mensuplai daya untuk memenuhi kebutuhan daya beban gedung DH apabila daya dibangkitkan PLTS dan Baterai lebih rendah dari daya kebutuhan beban gedung DH.

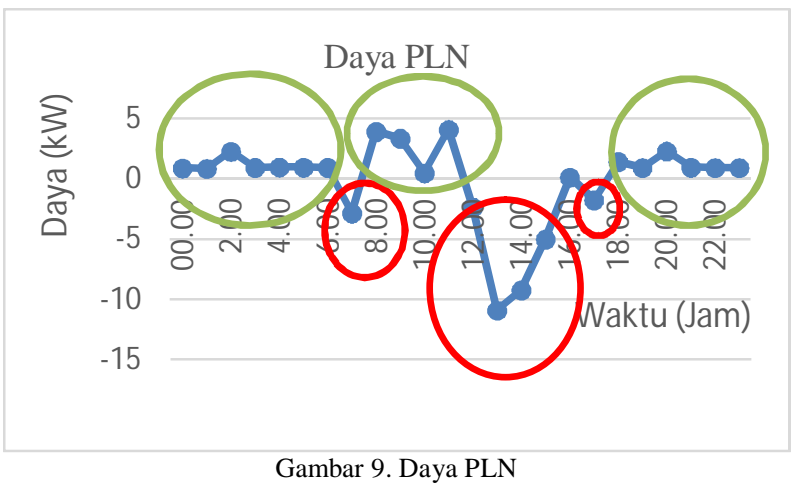

Pada Gambar 9 dapat dianalisis daya dari PLN bernilai positif (lingkaran hijau) maka sistem smart microgrid mengimpor daya dari PLN sedangkan ketika daya PLN bernilai negatif (lingkaran merah) maka sistem smart microgrid mengekspor daya ke PLN. Jaringan smart microgrid di JTE dari Gambar 9 mengekspor daya ke PLN pada pukul 07.00 WITA, 12.00 sampai dengan 14.00 WITA, 15.00 WITA dan 17.00 WITA dengan daya ekspor maksimum 10,9095 kW pada pukul 13.00 WITA. Sedangkan jaringan smart microgrid mengimpor daya dari PLN pada pukul 01.00 sampai pukul 6.00 
WITA, pukul 8.00 sampai pukul 11.00 WITA, pukul16.00 WITA, dan pukul 18.00 sampai pukul 24.00 WITA dengan daya maksimum $4,0714 \mathrm{~kW}$ pada pukul 11.00 WITA.

Pada prinsip jaringan smart microgrid di JTE saat on grid apabila daya yang dibangkitkan pada PLTS dan Baterai lebih kecil dari kebutuhan daya beban gedung DH maka kekurangan daya pembangkit akan disuplai dari daya PLN. Sedangkan saat pembangkitan PLTS dan Baterai lebih besar dari kebutuhan daya beban Gedung DH maka kelebihan daya akan disuplai ke PLN untuk disuplai pada daya kebutuhan beban areal gedung jurusan Teknik Elektro yaitu gedung DI dan Gedung DJ.

\section{F. Unjuk Kerja Smart Microgrid Sistem Hibrid di Jurusan Teknik Elektro (JTE)}

Unjuk kerja dari smart microgrid sistem hibrid di JTE diketahui dari suplai energi listrik dari masing-masing pembangkit pada smart microgrid sistem hibrid dalam memenuhi kebutuhan beban energi listrik Gedung DH.

TABEL 1.

ENERGI LISTRIK KOMPONEN SMART MICROGRID SISTEM HIBRID JURUSAN TEKNIK ELEKTRO

\begin{tabular}{|r|r|r|r|}
\hline $\begin{array}{r}\text { Komponen } \\
\text { Microgrid }\end{array}$ & $\begin{array}{r}\text { Energi Impor } \\
(\mathrm{kWh})\end{array}$ & $\begin{array}{r}\text { Energi Ekspor } \\
(\mathrm{kWH})\end{array}$ & $\begin{array}{r}\text { Total Energi } \\
(\mathrm{kWh})\end{array}$ \\
\hline PLTS Array 1 & 173,662 & 3 & 176,662 \\
\hline PLTS Array 2 & 159,721 & 0,001 & 159,722 \\
\hline Baterai & 803,57 & 1894,38 & $2.697,95$ \\
\hline PLTB & 121,07 & 193,29 & 314,36 \\
\hline PLN & 1591,7 & 541 & 2132,7 \\
\hline Beban & - & - & 4330 \\
\hline
\end{tabular}

Berdasarkan tabel 1 dapat di analisis hasil energi listrik dari komponen smart microgrid sistem hibrid di Jurusan Teknik Elektro pada bulan Oktober 2018 dari energi listrik PLTS 333,383 kWh, energi listrik baterai 803,57 kWh dan energi listrik PLTB 121,07 kWh. Energi listrik PLTB sepenuhnya dipakai untuk mengisi baterai sebesar 189,38 $\mathrm{kWh}$, dimana energi listrik PLTB tidak mencukupi untuk mengisi energi listrik baterai yang kekurangannya diambil dari energi listrik PLTS dan PLN sebesar 1894,38 - 121,07 = $1773,31 \mathrm{kWh}$. Kebutuhan energi listrik gedung DH sebesar $4330 \mathrm{kWh}$ pada bulan Oktober 2018. Dalam memenuhi kebutuhan energi listrik gedung DH masih membutuhkan energi listrik dari PLN sebesar 1591,7 kWh. Smart microgrid sistem hibrid di Jurusan Teknik Elektro memberikan konstribusi untuk memenuhi kebutuhan energi listrik beban gedung DH sebesar $4330-1591,7=2738,3 \mathrm{kWh}$. Hal ini menunjukan unjuk kerja pada smart microgrid sistem hibrid mencapai $(2738,3 / 4330) \times 100 \%=63,24 \%$ dalam pemanfatan energi baru terbarukan. Smart microgrid sistem hibrid di Jurusan Teknik Elektro tidak hanya memenuhi kebutuhan energi listrik beban gedung DH saja tetapi ada energi listrik yang diekspor ke PLN sebesar $541 \mathrm{kWh}$ yang dipakai untuk memenuhi kebutuhan energi listrik di gedung DI dan gedung

I.P Arsikaputra: Studi Unjuk Kerja Smart ...
DJ. Jaringan smart microgrid terdapat energi listrik yang terbuang pada saat PLTB tidak membangkitkan energi listrik sebesarnya 193,29 kWh.

\section{KESIMPULAN}

Berdasarkan data pada data logger smart microgrid sistem hibrid di Jurusan Teknik Elektro Fakultas Teknik Universitas Udayana pada tahun 2018 berdasarkan data 1 bulan saja yakni bulan Oktober 2018, hal ini karena bulan Oktober 2018 merupakan data paling lengkap dari bulan-bulan lain, maka penelitian tentang studi unjuk kerja smart microgrid sistem hibrid di Jurusan Teknik Elektro Fakultas Teknik Universitas Udayana dapat diambil kesimpulan bahwa smart microgrid sistem hibrid yang berbasiskan energi baru terbarukan hanya memenuhi kebutuhan energi listrik pada Gedung DH sebesar 2738,3 kWh dari total energi listrik dibutuhkan gedung DH sebesar $4330 \mathrm{kWh}$ masih menggunakan energi listrik dari PLN sebesar 1591,7 kWh sehingga pemanfaatan energi baru terbarukan mencapai $63,24 \% /$ bulan.

\section{REFERENSI}

[1] PT.PLN (PERSERO). 2019. RUPTL (Rencana Usaha Penyediaan Tenaga Listrik). Jakarta : Kementerian Energi dan Sumber Daya Mineral

[2] I.N.S. Kumara, W.G. Ariastina, I.W. Sukerayasa, I.A.D. Giriantari. 2014. On The Potential And Progress Of Renewable Electricity Generation in Bali. Yogyakarta. ICITEE 2014

[3] Pemerintah RI. 2017. Peraturan Presiden Nomor 22 Tahun 2017 Tentang Rancangan Umum Energi Nasional

[4] Giriantari I.A.D, Irawati. R. 2016. Smart Microgrid System with Hybrid System Supply: Udayana University Pilot Project Design. ICSGTEIS 2016

[5] Margareta Yuniari, I.A.D Giriantari, I.W. Sukerayasa. 2017. Analisa Model Supply Pada Jaringan Sistem Kelistrikan di Fakultas Teknik Universitas Udayana Bukit Jimbaran. Jurnal Teknik Elektro. Vol 16 No 03

[6] Trisnasari C.T. 2016. Pemodelan dan Simulasi Sistem Proteksi Microgrid. Jurnal Teknik ITS. Vol 5 No 2.48-52.

[7] Nyserda. http://www.Nyserda.ny.gov/All-program/Program/NYPrize/Resorce-for applicants/Microgrid-101. [Online]. Diakses pada Oktober 2018

[8] N. Wicaksono, R.S. Wibowo, H. Suryoatmojo. 2016. Economic dispath untuk Sistem Kelistrikan Microgrid dengan Energy Storage berbasis Adaptive Particle Swarm Optimization. Jurnal Teknik ITS. Vol 5 No 2

[9] S Manalu, C.O.P. Marpaung.2019. Techno Economic Analysis of a Microgrid System to Increase Electricity Acces in Rural Areas. IJSGSET Transsactions on Smart Grid and Sustainable Energy. Vol 3 No 2

[10] H.Kristiawan, I.N.S Kumara, I.A.D Giriantari. 2019. Potensi Pembangkit Listrik Tenaga Surya Atap Gedung Sekolah di Kota Denpasar. Jurnal Spektrum. Vol 6 No 2

[11] K.V. Kumara, I.N.S. Kumara, W.G. Ariastina. 2018. Tinjauan Terhadap PLTS $24 \mathrm{~kW}$ Atap Gedung PT Indonesia Power Pesanggaran Bali. E-Journal Spektrum. Vol 5 No 2

[12] M.R. Wicaksan, I.N.S. Kumara, I.A.D.Giriantari, R. Irawati. 2019 Unjuk Kerja Pembangkit Listrik Tenaga Surya Rooftop 158 kWp Pada Kantor Gubernur Bali. Jurnal Spektrum. Vol 6 No 3

[13] N.S. Gunawan, I.N.S. Kumara, R.Irawati. 2019. Unjuk Kerja Pembangkit Listrik Tenaga Surya (PLTS) 26,2 kWp Pada Sistem Smart Microgrid Unud. Jurnal Spektrum . Vol 6 No 3

[14] I.A. Medina, I A D Giriantari, I. W Sukerayasa. 2018. Kajian dan Evaluasi Sistem Suplai Energi Listrik PLTS dan PLTB di Kampus

p-ISSN:1693 - 2951; e-ISSN: 2503-2372 
Teknik Elektro Universitas Udayana Bukit Jimbaran Bali. Majalah Ilmiah Teknologi Elektro. Vol.17,No.3. 